\title{
Rapid Protein Release from Escherichia coli by Chemical Permeabilization Under Fermentation Conditions
}

\author{
Thomas J. Naglak* and Henry Y. Wang ${ }^{\dagger}$ \\ Department of Chemical Engineering, The University of Michigan, \\ Ann Arbor, MI 48109
}

Received February 11, 1991/Accepted September 27, 1991

\begin{abstract}
Overall protein release greater than $75 \%$ in less than $1 \mathrm{~h}$ can be attained by exposing exponentially growing Escherichia coli cells to $0.4 \mathrm{M}$ guanidine plus $0.5 \%$ Triton $X-100$ at $37^{\circ} \mathrm{C}$ in medium. Cell growth stops immediately upon addition of the chemicals, but the cells are not lysed. Guanidine concentrations lower than $0.2 \mathrm{M}$, in conjunction with $0.5 \%$ Triton $X-100$, do not release significant intracellular protein, nor do they inhibit cell growth. Under these conditions, the cells undergo an adaptation that confers resistance to protein release by further treatment with guanidine and Triton X-100. Cells treated with $0.2 \mathrm{M}$ guanidine plus $0.5 \%$ Triton $X-100$ display intermediate behavior. Protein release is approximately $35 \%$, and growth is temporarily interrupted by an extended lag phase. Subsequent resumption of cell growth results in resistant celis and no additional protein release. This resistance is shown to be reversible and is most likely due to physiological adaptation rather than genetic mutation. Keywords: cell disruption - chemical permeabilization Escherichia coli • fermentation - protein recovery
\end{abstract}

\section{INTRODUCTION}

Previous work in our laboratory has demonstrated that chemical permeabilization by guanidine and Triton $\mathrm{X}-100$ can release significant overall protein and active enzymes from Escherichia coli. ${ }^{5,9}$ These previous experiments were conducted using $E$. coli cells suspended in buffer at $4^{\circ} \mathrm{C}$. These conditions were selected as representative of many typical protein recovery operations, and because the low temperature inhibits protein degradation by native proteases. The low temperature also prevents growth and division of the cells, meaning that protein release by chemical permeabilization can occur independent of cell growth. However, many investigators have successfully undertaken to induce $E$. coli, either by secretion or by "leaking," to release proteins during active growth. ${ }^{1,3,6-8}$ Such release often has advantages for protein recovery over using a separate cell disruption stage such as mechanical lysis or chemical permeabilization. However, attaining secreting or leaky strains is the result of genetic engineering and may not be practical or successful in all cases. ${ }^{11}$ Thus, the current studies were undertaken to determine whether protein release by chemical permeabilization could occur

\footnotetext{
* Present address: R.W. Johnson Pharmaceutical Research Institute, Route 202, P.O. Box 300, Raritan, NJ 08869.

${ }^{\dagger}$ To whom all correspondence should be addressed.
}

under conditions that may allow for cell growth and what effect on cell growth such release might have. The ultimate objective of this work was to develop a simple method for attaining rapid protein release from $E$. coli under fermentation conditions without resorting to genetic engineering.

\section{MATERIALS AND METHODS}

\section{Microorganism and Culture Conditions}

E. coli $\mathrm{C} 600-1$ (supplied by Professor Tadayuki Imanaka of Osaka University, Japan) was maintained at $-20^{\circ} \mathrm{C}$ in $50 \%$ (vol/vol) glycerol. Cultures were grown in modified L-broth (MLB) at $37^{\circ} \mathrm{C}$ in shake flasks. MLB contains, per liter distilled water, $10 \mathrm{~g}$ yeast extract, $20 \mathrm{~g}$ tryptone, $0.5 \mathrm{~g} \mathrm{NaCl}$, and $5 \mathrm{~g}$ cerelose (DSM Foods, Detroit, MI). The $\mathrm{pH}$ was adjusted to 7.0 prior to autoclaving, and filter sterilized tetracycline was added to $20 \mu \mathrm{g} / \mathrm{mL}$ after autoclaving.

\section{Effect of Permeabilization Chemicals on Growth of $E$. coli}

Prior to inoculation, solutions of guanidine and/or Triton $\mathrm{X}-100$ in $0.05 M$ phosphate $(\mathrm{pH} \mathrm{7)}$ were added to MLB to give final concentrations as indicated. The ratio of MLB to treatment chemicals in buffer was 11.1 volumes to 1 volume. The control consisted of buffer added to MLB. Triplicate flasks were inoculated at 100:1 dilution using an overnight culture grown in MLB.

Growth was monitored by turbidity, in Klett units, with a Klett-Summerson Photoelectric Colorimeter 800-3 equipped with a red filter (Kletts $=\mathrm{OD} \times 1000 / 2$; i.e., 250 Kletts $=0.5 \mathrm{OD}$ ). The lag phase was judged to be over when the turbidity increased detectably above the initial value measured upon inoculation. When growth had progressed to approximately 300 Kletts, each flask was subcultured at 100:1 dilution to a new flask of medium containing identical guanidine and Triton X-100 concentrations. Overall protein and $\beta$-lactamase release data are reported for the first of these subcultures, i.e., the second culture grown in the presence of treatment chemicals. 


\section{Permeabilization of Growing E. coli Cells}

Overnight cultures grown in MLB were inoculated to fresh MLB at 100:1 dilution and grown to approximately 200 Kletts (stationary phase corresponds to approximately $400-500$ Kletts). The cells were then aseptically aliquoted to sterile flasks. Sterile solutions of guanidine and/or Triton X-100 in $0.05 \mathrm{M}$ phosphate (pH 7) were added to give final concentrations as indicated. The ratio of cells in medium to treatment chemicals in buffer was three volumes to one volume. The control consisted of sterile buffer added to cells. The flasks were then returned to constant shaking at $37^{\circ} \mathrm{C}$. Samples were aseptically withdrawn at the indicated intervals, centrifuged, decanted, and saved at $4^{\circ} \mathrm{C}$ for assay later the same day.

For the experiments depicted in Figure 6, treated cells were allowed to grow overnight $(18-20 \mathrm{~h})$. These cells were then used to inoculate new cultures in MLB at 20:1 dilution, either by direct inoculation or by passing treated cells that were washed four times in sterile MLB by centrifugation and resuspension, with a control consisting of treated cells centrifuged and resuspended in the original supernatant four times. These new cultures were allowed to grow to approximately 200 Kletts and then treated again by dilution with sterile treatment chemicals, three volumes of cells to one volume of treatment chemicals.

In addition, overnight treated cells that had grown were plated out on MLB made solid by addition of $20 \mathrm{~g} / \mathrm{L}$ agar. Cells were plated at several dilutions, made serially in sterile MLB. Three separate colonies were transferred from plates to fresh liquid MLB using a sterile wooden stick and grown overnight in suspension. These three cultures were then diluted 100:1 in fresh MLB, grown to approximately 200 Kletts, and treated again in the manner of dilution with sterile treatment chemicals.

Plating efficiencies were determined as follows. An overnight culture of control cells in MLB was streaked out on MLB, MLB plus $0.002 M$ guanidine plus $0.005 \%$ Triton X-100, MLB plus $0.02 M$ guanidine plus $0.05 \%$ Triton $\mathrm{X}-100$, and MLB plus $0.2 M$ guanidine plus $0.5 \%$ Triton $X-100$. The plates were incubated for $24 \mathrm{~h}$ at $37^{\circ} \mathrm{C}$, and then the colonies were counted on triplicate plates.

\section{Protein Assay}

Protein was determined by the method of Bradford ${ }^{2}$ using bovine serum albumin as the standard. Interference by Triton X-100 was accounted for by ensuring that all samples and standards had identical Triton X-100 concentrations of $0.5 \%$ or less. Total cellular protein was determined by lysing samples of whole broth in $1 \mathrm{M}$ $\mathrm{NaOH}$ at $100^{\circ} \mathrm{C}$ for $7 \mathrm{~min}$. Standards for the determination of total cellular protein were also exposed to the hot alkali treatment. Protein release is reported as the percentage of protein found in the supernatant based on separate supernatant and total cellular protein assays and employing a gravimetrically determined correction factor for the volume of the pellet.

\section{$\beta$-lactamase Assay}

$\beta$-lactamase (E.C. 3.5.2.6) activity was determined by application of the fixed time method of Sargent. ${ }^{10} \mathrm{~A}$ $0.1-\mathrm{mL}$ sample was added to $0.4-\mathrm{mL}$ assay buffer $(0.05 M$ phosphate, $\mathrm{pH} \mathrm{7)}$ at room temperature. The reaction was initiated by adding $0.1 \mathrm{~mL}$ benzylpenicillin $(4 \mathrm{mg} / \mathrm{mL}$ of the potassium salt in assay buffer). After incubation at room temperature for a specified time, the reaction was halted by adding $1 \mathrm{~mL}$ iodine reagent. The iodine reagent is prepared as follows: stock solution (20.3 $\mathrm{g} \mathrm{I}_{2}, 100 \mathrm{~g} \mathrm{KI}$, in $500 \mathrm{~mL}$ distilled water) is diluted $20: 1$ immediately prior to use in acetate buffer ( $40 \mathrm{~g}$ sodium acetate in distilled water with glacial acetic acid as necessary to make $1 \mathrm{~L}$ final buffer, $\mathrm{pH} 4.0$ ). Within minutes of quenching, the absorbance was read at $540 \mathrm{~nm}$. Included for each assay was a buffer blank or a Triton X-100 blank (buffer containing a Triton X-100 concentration identical to the sample). Enzyme activity is defined in arbitrary units as

$$
\frac{A_{540}(\text { blank })-A_{540}(\text { sample })}{\text { incubation time }}
$$

and are reported in $\Delta$ milliOD $_{540} / \mathrm{min}$. Triton X-100 concentrations in samples were diluted to $0.006 \%$ or less to prevent interference. Total intracellular $\beta$-lactamase activity in $E$. coli was determined by disrupting samples of whole broth with sonication. Aliquots of $100 \mu \mathrm{L}$ were disrupted in four discrete 5-s treatments with the microtip of a Fisher Sonic Dismembrator Model 300 at $35 \%$ power. Between sonication bursts, samples were cooled on ice. After sonication, samples were centrifuged for $30 \mathrm{~min}$ at $15,000 \mathrm{~g}$ and the supernatants were assayed for total $\beta$-lactamase.

It should be noted that total intracellular protein and total intracellular $\beta$-lactamase were based on two different extraction methods, hot alkali and sonication. This is because hot alkali also serves to solubilize membrane and wall proteins that sediment with a sonicated pellet. Assays revealed that pellets from sonicates showed no detectable $\beta$-lactamase activity.

\section{Cell Counts and Cell Size Distributions}

Cell counts and cell size distributions were determined with a Coulter Counter ZM equipped with a $30-\mu \mathrm{m}$ orifice tube and connected to a Coulter Channelyzer 256 (Coulter Electronics, Inc., Hialeah, FL). Cell samples were fixed by adding $100 \mu \mathrm{L}$ sample to $4.9 \mathrm{~mL}$ fixative $(0.2 \%$ formaldehyde in $0.85 \% \mathrm{NaCl})$ and stored at $4^{\circ} \mathrm{C}$ prior to counting. Reported values are all the average of two determinations. 


\section{RESULTS AND DISCUSSION}

\section{The Effect of Protein Release on Cell Growth}

Initial experiments involved inoculating $E$. coli cells to medium containing treatment chemicals. Based on earlier detailed experiments conducted at $4^{\circ} \mathrm{C},{ }^{9}$ the concentrations selected for this initial study were $0.2 \mathrm{M}$ guanidine and $0.2 \mathrm{M}$ guanidine plus $0.5 \%$ Triton X-100. Treatment by $0.2 \mathrm{M}$ guanidine releases periplasmic proteins, whereas treatment by $0.2 \mathrm{M}$ guanidine plus $0.5 \%$ Triton X-100 releases both periplasmic and cytoplasmic proteins from $E$. coli at $4^{\circ} \mathrm{C} .{ }^{9}$

Figure 1 shows the growth curves of these cultures (expressed as "Relative Time" since the end of the lag phase). The growth of cultures in medium containing these concentrations of the treatment chemicals is very similar to growth of control cultures in regular medium. The major difference is that the lag phase increases for the cells subcultured from regular medium to medium containing treatment chemicals, as shown in Table $\mathbf{I}$. This is to be expected because the cells must accustom themselves to the different environment. Once acclimated, however, the cells grow at the same growth

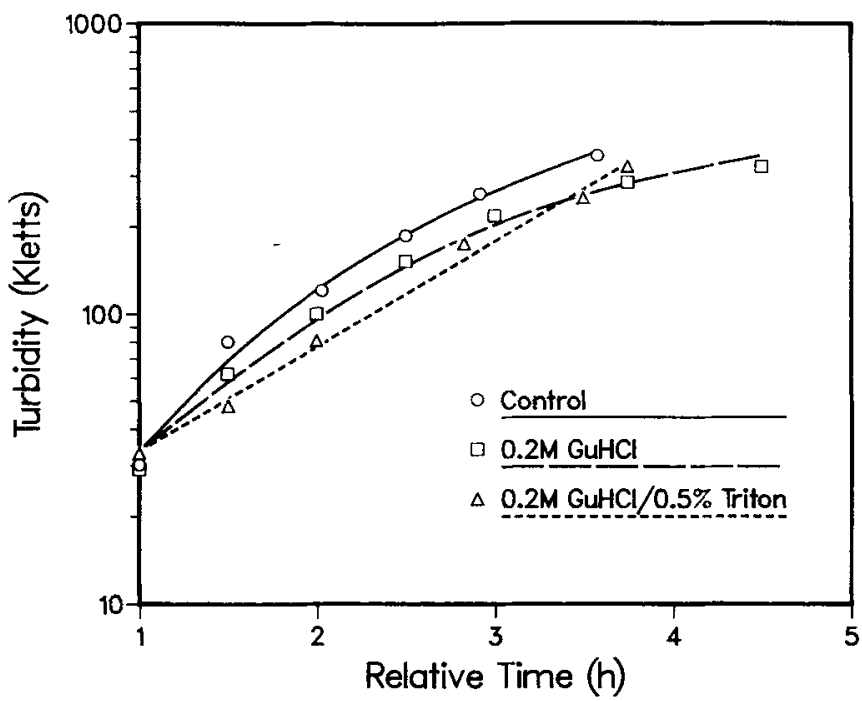

Figure 1. Growth curves for E. coli C600-1 grown in control medium and in medium containing treatment chemicals. Turbidity data is plotted against "Relative Time," meaning that time zero has been defined as the end of the lag phase for each particular culture. The length of the lag phase varies for each culture (see Table I). rate as control cultures, to within statistical deviations (Table I). Subsequent passages in medium containing treatment chemicals result in no longer a lag phase than for control cultures.

Table II shows release of overall protein and of $\beta$-lactamase, a particular periplasmic protein, for a control culture and for cultures grown in the presence of $0.2 \mathrm{M}$ guanidine or $0.2 \mathrm{M}$ guanidine plus $0.5 \%$ Triton $\mathrm{X}-100$. The amount of overall protein and $\beta$-lactamase detected in the supernatant of the control culture is very low, as expected. The amount of overall protein and $\beta$-lactamase released by the experimental cultures, however, is even lower, indicating that cells grown in the presence of these chemicals have become resistant to their effects for releasing periplasmic and cytoplasmic proteins.

In order to assure that this inhibited protein release was not due to the cells being suspended in growth medium rather than in buffer or due to the cells being held at $37^{\circ} \mathrm{C}$ rather than at $4^{\circ} \mathrm{C}$, a batch of cells was grown to midexponential phase in regular medium and then directly diluted with treatment chemicals in medium (instead of being washed and diluted with treatment chemicals in buffer). A portion of these cells was incubated at $37^{\circ} \mathrm{C}$, and a portion was incubated at $4^{\circ} \mathrm{C}$. Figure 2 shows the results of this experiment. At $37^{\circ} \mathrm{C}$, the cells rapidly release a large amount of overall protein. After several hours, growth resumes. After $21 \mathrm{~h}$, the cells at $37^{\circ} \mathrm{C}$ grow about 20 -fold over their initial concentration. However, there is no more protein present in the supernatant than was present before the cells resumed growth (data not shown), consistent with the observations from Table II. At $4^{\circ} \mathrm{C}$, the cells release protein much more slowly, as occurs for cells treated in buffer. Of course, the cells do not resume growth at $4^{\circ} \mathrm{C}$. After $21 \mathrm{~h}$ at $4^{\circ} \mathrm{C}$, the cells release about $60 \%$ of their overall protein (data not shown), consistent with the protein release observed in buffer at $4^{\circ} \mathrm{C} .{ }^{9}$

Inoculating $E$. coli cultures to medium containing treatment chemicals seems to prevent protein release by chemical permeabilization by allowing the cells time to adapt to the presence of the chemicals. However, treating the cells at $37^{\circ} \mathrm{C}$ rather than $4^{\circ} \mathrm{C}$ results in much more rapid protein release. Thus, a new series of experiments was conducted whereby treatment chemicals were added to rapidly growing cultures at $37^{\circ} \mathrm{C}$ to determine

Table I. Lag phases and growth rates for $E$. coli $\mathrm{C} 600-1$ cultures grown in control medium and in medium containing treatment chemicals.

\begin{tabular}{|c|c|c|c|c|}
\hline & \multicolumn{2}{|c|}{ Lag phase } & \multicolumn{2}{|c|}{ Specific growth rate } \\
\hline & 1st Culture & 2nd Culture & Growth rate & Standard deviation \\
\hline Control & $2 \mathrm{~h}$ & $2 \mathrm{~h}$ & $1.04 \mathrm{~h}^{-1}$ & $0.097 \mathrm{~h}^{-1}$ \\
\hline $0.2 M$ Guanidine & 12 & 2 & 0.87 & 0.14 \\
\hline $0.2 M$ Guanidine $/ 0.5 \%$ Triton $\mathrm{X}-100$ & 15 & 2 & 0.89 & 0.066 \\
\hline
\end{tabular}

The first culture was inoculated at 100:1 dilution using cells grown in control medium, but the second culture was inoculated at 100:1 dilution using the first culture, and so on for subsequent cultures. Growth rates for cultures grown in medium containing treatment chemicals based only on second and third cultures in the presence of chemicals. Standard deviations based on 6 determinations. 
Table II. Whole broth and supernatant protein and $\beta$-lactamase concentrations for $E$. coli C600-1 cultures during exponential growth at $37^{\circ} \mathrm{C}$ in medium with and without $0.2 \mathrm{M}$ guanidine or $0.2 \mathrm{M}$ guanidine plus $0.5 \%$ Triton X-100 present.

\begin{tabular}{lcccc}
\hline & $\begin{array}{c}\text { Whole broth protein } \\
(\mathrm{mg} / \mathrm{mL})\end{array}$ & $\begin{array}{c}\text { Supernatant protein } \\
(\mathrm{mg} / \mathrm{mL})\end{array}$ & $\begin{array}{c}\text { Whole broth } \beta \text {-lactamase } \\
\text { (arb. units) }\end{array}$ & $\begin{array}{c}\text { Supernatant } \beta \text {-lactamase } \\
(\mathrm{arb} . \text { units })\end{array}$ \\
\hline Control & 0.31 & 0.012 & 237 & 18 \\
$0.2 M$ Guanidine & 0.30 & 0.005 & 230 & 3 \\
$0.2 M$ Guanidine/0.5\% Triton X-100 & 0.33 & 0.009 & 280 & 0 \\
\hline
\end{tabular}

if growth would continue and if protein release would occur coincident with such growth.

Cells were grown until midexponential phase in control medium in shake flasks. Three volumes of culture was then diluted with one volume of sterile treatment chemicals in buffer and returned to shaking at $37^{\circ} \mathrm{C}$. Figure 3(A) shows the control for these experiments. Specifically, this consists of aseptically adding buffer to the cells at time zero. The culture continues to grow, as measured by turbidity, cell number, and whole broth protein. The $\mathrm{pH}$ decreases, typical of an $E$. coli culture.

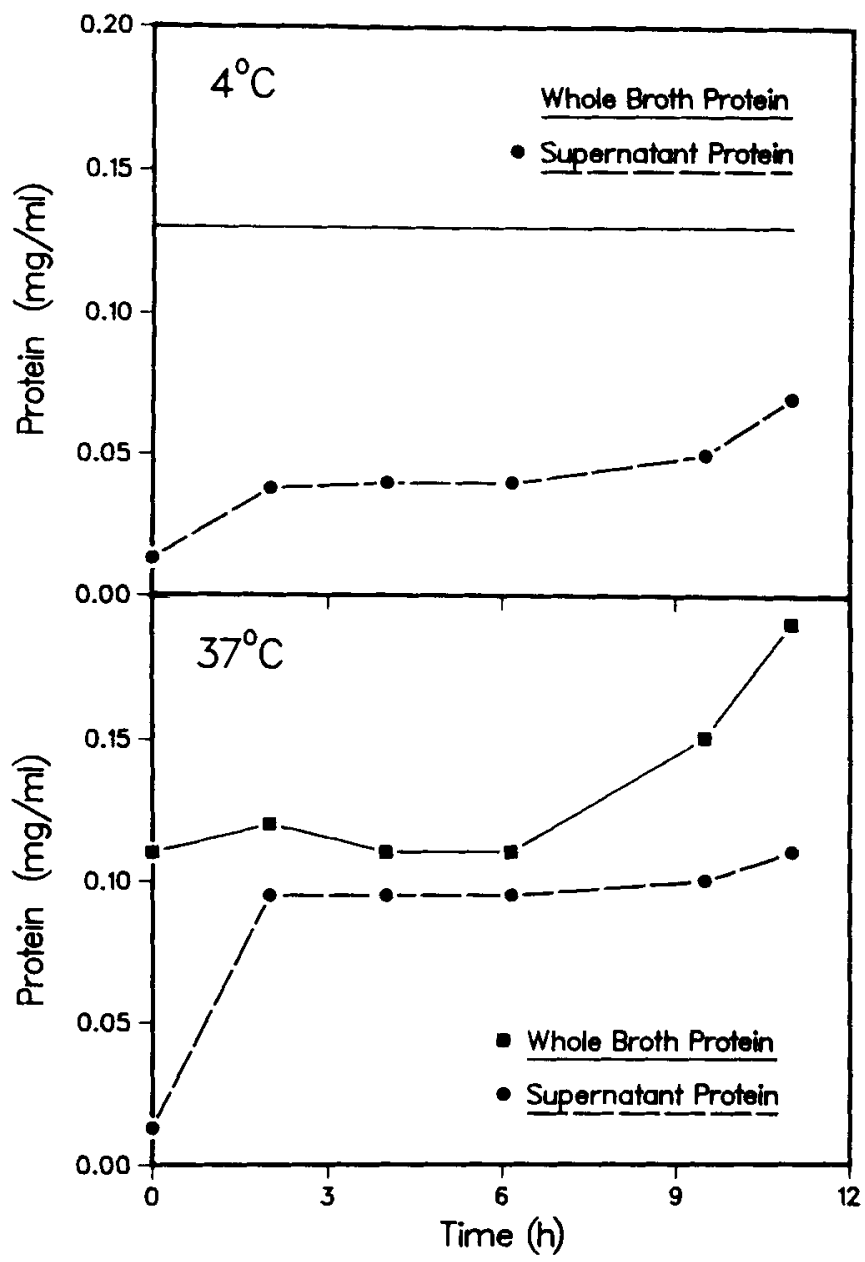

Figure 2. Whole broth and supernatant protein concentrations for $E$. coli $\mathrm{C} 600-1$ cultures exposed to $0.2 \mathrm{M}$ guanidine plus $0.5 \%$ Triton X-100 in medium at $4^{\circ} \mathrm{C}$ and at $37^{\circ} \mathrm{C}$. Because growth does not occur at $4^{\circ} \mathrm{C}$, a single assay serves to determine the whole broth protein concentration for the entire exposure; hence, the solid line rather than discrete data points for whole broth protein in the top plot.
The amount of protein detectable in the supernatant is very low, also typical of an $E$. coli fermentation.

Figure 3(B) shows the same data for a culture treated with $0.2 \mathrm{M}$ guanidine and $0.5 \%$ Triton X-100. Growth stops immediately upon addition of the chemicals, and approximately $35 \%$ of overall protein is released into the supernatant in the first three $h$. The turbidity declines slightly, but as we shall see in Figure 4, this is due to shrinkage of the cells, not cell lysis. The cell number remains the same throughout the first $3 \mathrm{~h}$ of the treatment, within $95 \%$ confidence limits.

Protein release by guanidine and Triton X-100 seems to be incompatible with continued growth of $E$. coli C600-1 under these conditions. Table III shows the composite results of a series of experiments identical to those depicted in Figure 3. At guanidine concentrations less than $0.2 \mathrm{M}$, coupled with $0.5 \%$ Triton X-100, cells continue to grow but release very little protein. For $0.5 \%$ Triton $\mathrm{X}-100$ plus guanidine concentrations of $0.2 M$ or greater, significant protein release occurs, but cell growth ceases. Even with modest guanidine concentrations of $0.3-0.4 M$, overall protein release can exceed $75 \%$ without lysis of the cells, but at the expense of continued cell growth. For the particular case of exponentially growing cells suddenly exposed to $0.2 \mathrm{M}$ guanidine plus $0.5 \%$ Triton X-100, cell growth will resume, but only after a suitably long lag phase, and with no additional protein release. $E$. coli cells treated with $0.4 \mathrm{M}$ guanidine plus $0.5 \%$ Triton X-100 do not resume growth, even after 2 days exposure. These latter cells are not dead, however, because transferring them to fresh medium lacking treatment chemicals results in new growth.

Figure 4 shows cell size distributions for control cells, for cells treated with $0.2 \mathrm{M}$ guanidine plus $0.5 \%$ Triton $\mathrm{X}-100$, and for cells treated with $0.4 M$ guanidine plus $0.5 \%$ Triton X-100. The treated cells shrink dramatically. It is interesting to note that the distribution for the cells treated with $0.2 \mathrm{M}$ guanidine plus $0.5 \%$ Triton $\mathrm{X}-100$ is bimodal. One peak may correspond to control cells, and one peak may correspond to permeabilized cells. Such behavior could indicate that the culture is made up of heterogeneous subpopulations, consistent with earlier studies of chemical permeabilization of a native strain of $E$. coli by transmission electron microscopy. ${ }^{4}$

Even in the absence of continued cell growth, the protein release results are still significant. As shown in Figure $5,75 \%$ protein release can be attained in less 


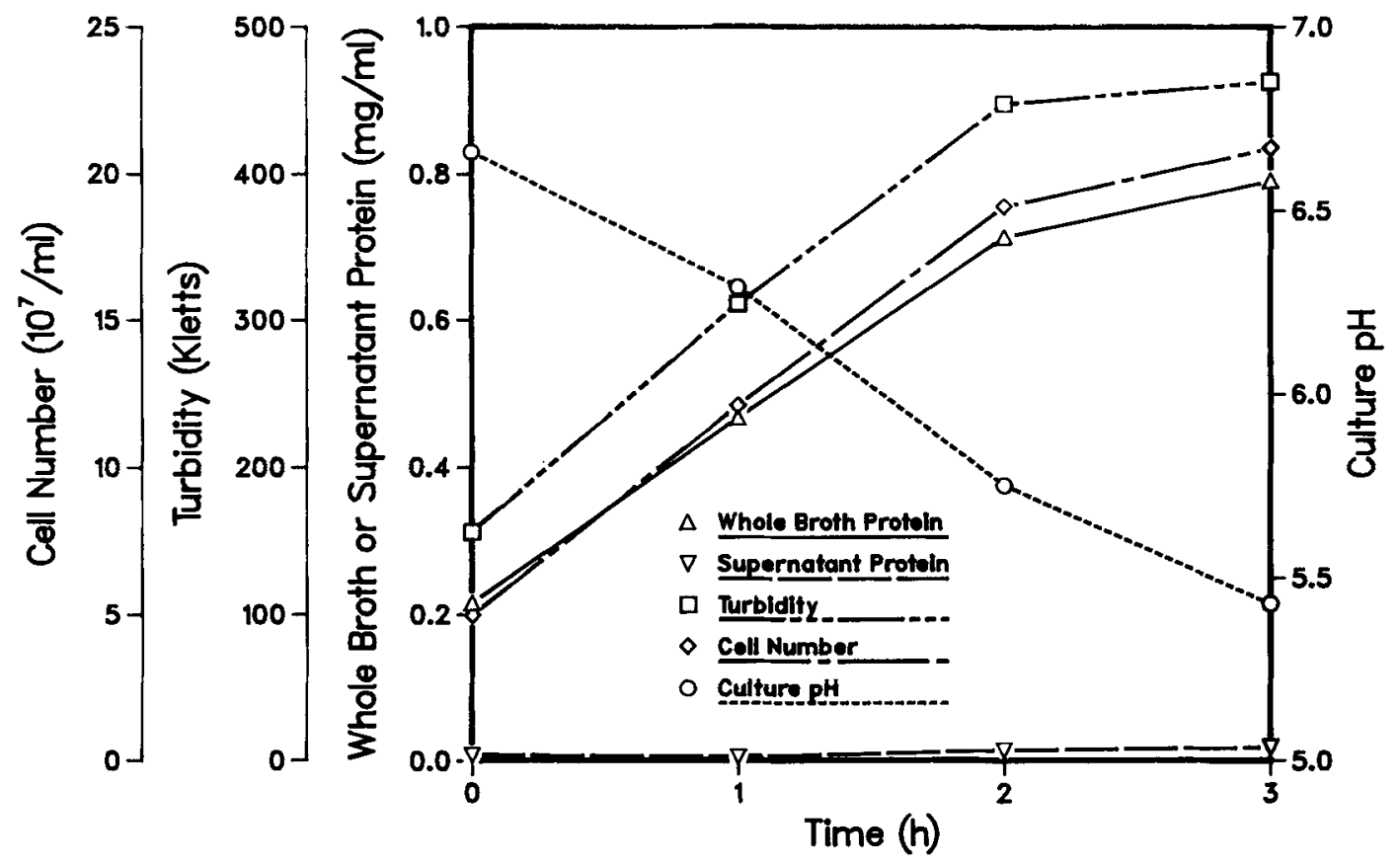

(A)

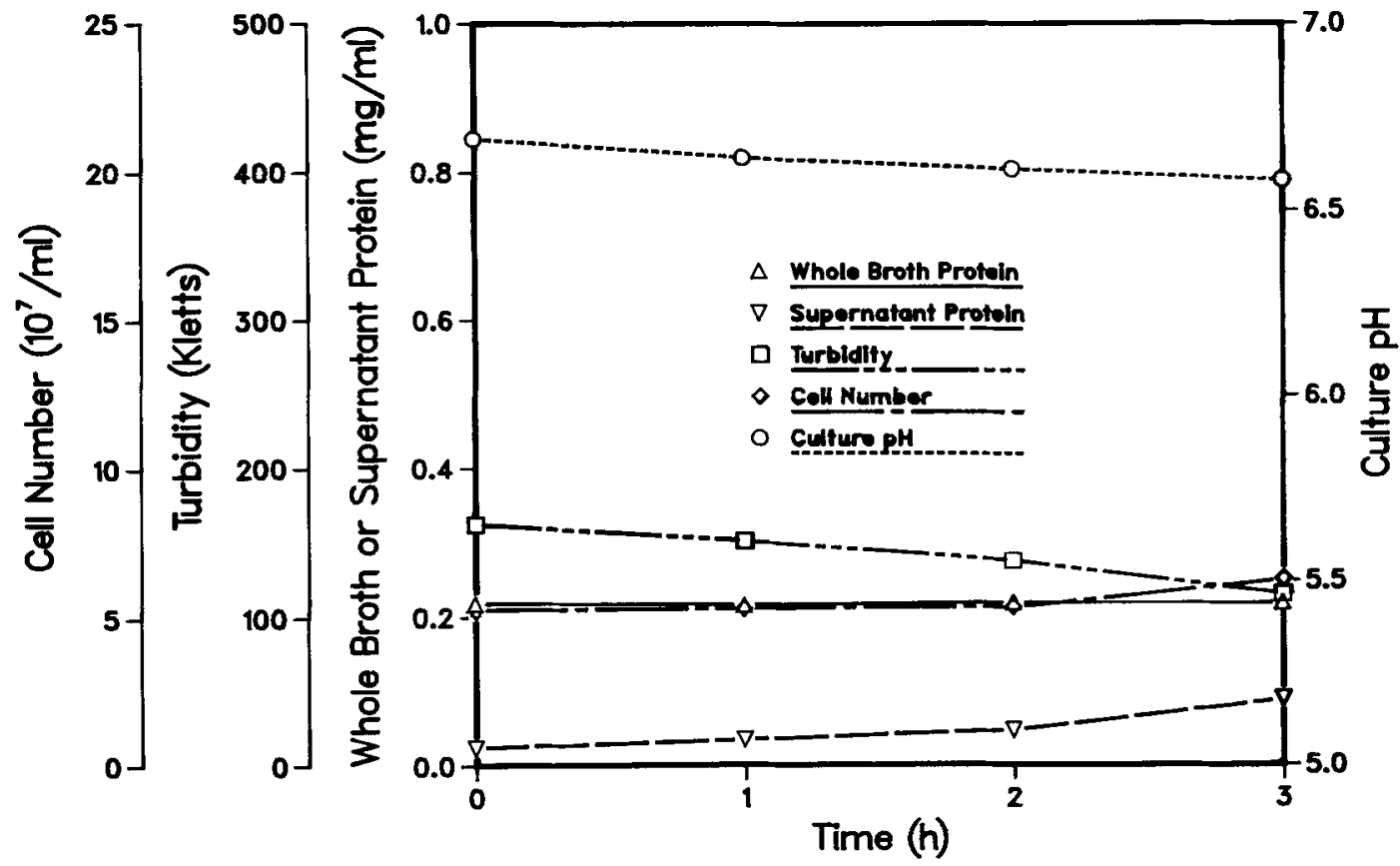

(B)

Figure 3. (A) Fermentation profile of a control E. coli C600-1 culture. At time zero, one volume of sterile buffer was added to three volumes of culture. (B) Fermentation profile of an $E$. coli C600-1 culture treated with $0.2 \mathrm{M}$ guanidine plus $0.5 \%$ Triton X-100. At time zero, one volume of sterile treatment chemicals in buffer was added to three volumes of culture.

than $1 \mathrm{~h}$ by treating the cells with $0.4 \mathrm{M}$ guanidine plus $0.5 \%$ Triton $\mathrm{X}-100$. The procedure is very simple and does not result in lysis of the cells. Chemical permeabilization by guanidine and Triton $\mathrm{X}-100$, thus, is a very attractive alternative to mechanical disruption for recovery of proteins that $E$. coli cannot be genetically engineered to secrete.
The Effect of $0.2 M$ Guanidine plus $0.5 \%$ Triton $\mathrm{X}-100$ on E. coli C600-1: Genetic Mutation or Physiological Adaptation?

The experiments presented in Table I and Figure 1 cannot differentiate between either of two possible explanations for the extended lag phase when cells are exposed to $0.2 \mathrm{M}$ guanidine plus $0.5 \%$ Triton X-100. In particu- 

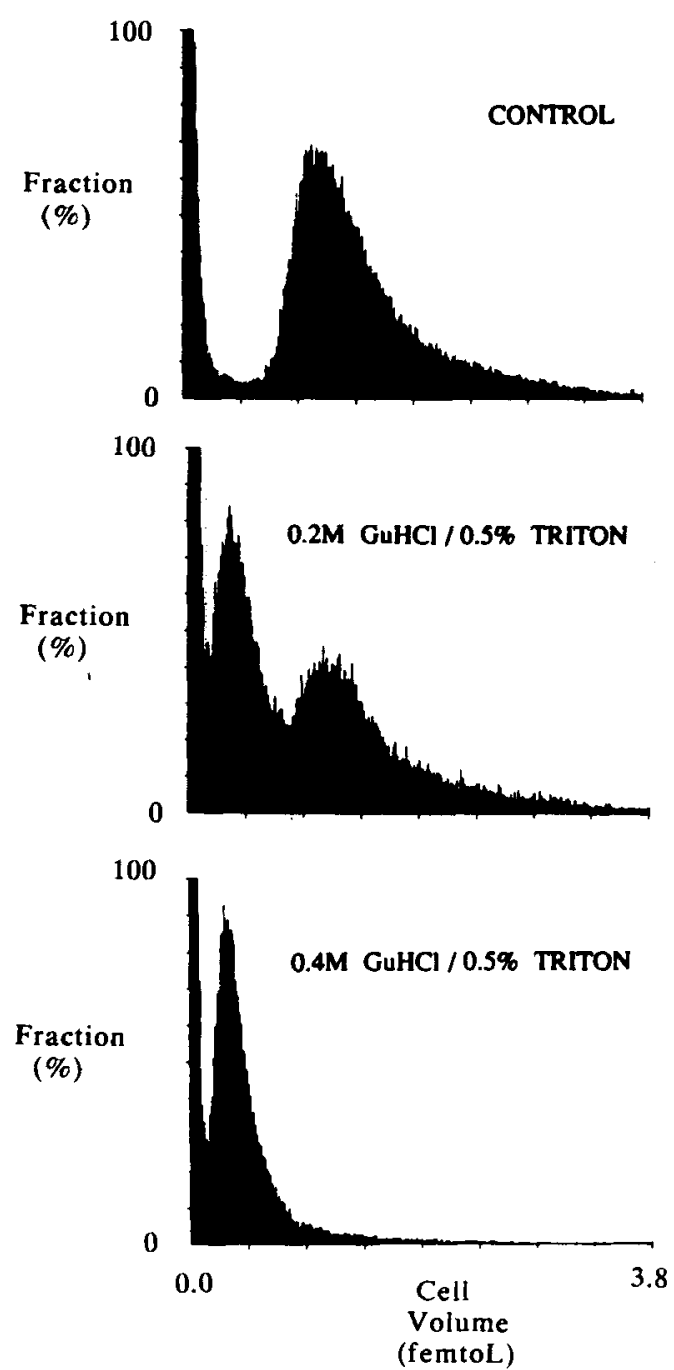

Figure 4. Cell size distribution for $E$. coli $\mathrm{C} 600-1$ cultures $3 \mathrm{~h}$ after sudden exposure to varying amounts of guanidine and Triton X-100 during exponential growth. The control consists of cells exposed to buffer.

Table III. Continued growth versus protein release for $E$. coli C600-1 cultures suddenly exposed to varying amounts of guanidine and Triton X-100 during exponential growth.

\begin{tabular}{lcc}
\hline & $\begin{array}{c}\text { Growth continues } \\
\text { upon exposure? }\end{array}$ & $\begin{array}{c}\text { Protein release } \\
\text { after } 3 \mathrm{~h} \text { exposure } \\
(\%)\end{array}$ \\
\hline $\begin{array}{l}\text { Control } \\
0.05 M \text { Guanidine/ } \\
0.5 \% \text { Triton } \mathrm{X}-100\end{array}$ & Yes & 2.4 \\
$\begin{array}{l}0.1 M \text { Guanidine/ } \\
0.5 \% \text { Triton } \mathrm{X}-100\end{array}$ & Yes & 5.1 \\
$\begin{array}{c}0.2 M \text { Guanidine/ } \\
0.5 \% \text { Triton X-100 }\end{array}$ & Yes & 6.8 \\
$\begin{array}{c}0.3 M \text { Guanidine/ } \\
0.5 \% \text { Triton X-100 }\end{array}$ & No & 35 \\
$0.4 M$ Guanidine/ & No & 83 \\
$0.5 \%$ Triton X-100 & No & 78 \\
\hline
\end{tabular}

Note: Growth resumes during overnight exposure.

The control consists of cells exposed to buffer. Protein release figures are the average of two determinations using different precultures.

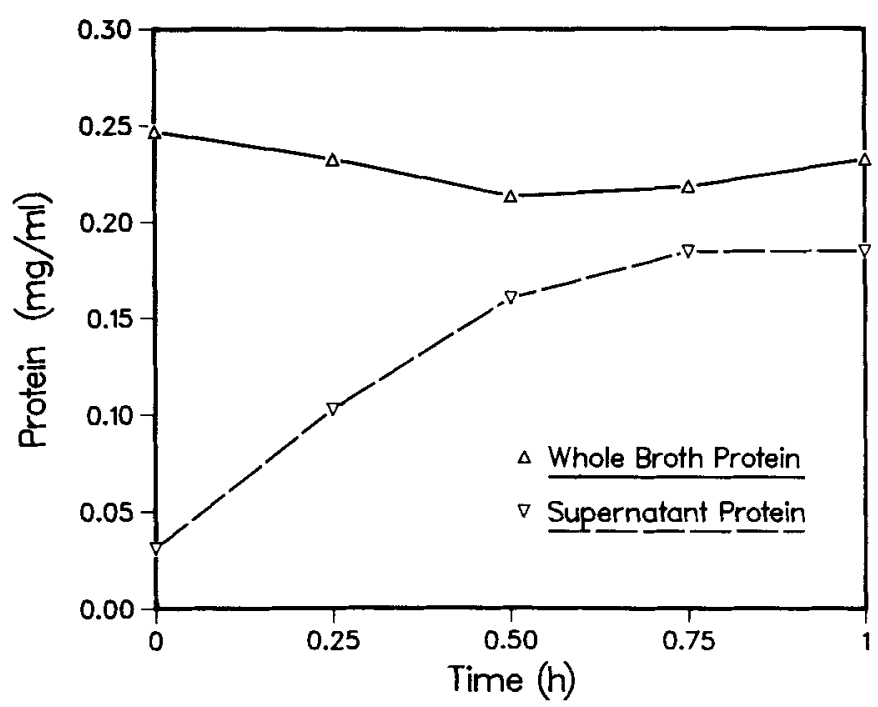

Figure 5. Whole broth and supernatant protein concentrations for an $E$. coli C600-1 culture suddenly exposed $0.4 M$ guanidine and $0.5 \%$ Triton X-100 during exponential growth. At time zero, one volume of sterile treatment chemicals in buffer was added to three volumes of culture.

lar, does this extended lag phase select for a subpopulation with a genetic mutation, or does it allow the entire culture to adapt by physiologic means? Several different experiments were conducted in an attempt to address this issue.

The first of these experiments involved subculturing cells that have grown in the presence of $0.2 \mathrm{M}$ guanidine plus $0.5 \%$ Triton $\mathrm{X}-100$. Initially, these cells show resistance to further treatment. Figure 6 shows that such cells that have been subcultured in regular medium maintain their resistance to the treatment, at least for a few generations. That is, the cells continue to grow and do not release significant protein upon addition of the treatment chemicals. This temporary resistance is not dependent upon presence of the treatment chemicals, as indicated by the washed cells (last set of bars in Fig. 6).

This resistance to further treatment can be lost from the cells given a sufficient number of generations growth in the absence of treatment chemicals, as shown in Table IV. Because the growth rates of treated cultures and control cultures is nearly identical, this loss of resistance probably indicates the reversing of an induced physiological change, not the overgrowth of the culture by a genetic subpopulation consisting of the original nonresistant strain.

Trace amounts of the treatment chemicals present during growth can elicit partial resistance ot the $0.2 \mathrm{M}$ guanidine plus $0.5 \%$ Triton X-100 treatment. The plating efficiency of control cells on solid medium containing a 100:1 dilution of $0.2 \mathrm{M}$ guanidine plus $0.5 \%$ Triton $\mathrm{X}-100$ is $41 \%$ compared to cells grown on regular, solid medium. Similarly, the plating efficiency of control cells on solid medium containing a 10:1 dilution of $0.2 M$ guanidine plus $0.5 \%$ Triton $\mathrm{X}-100$ is $23 \%$. However, as Figure 7 shows, these low concentrations of 


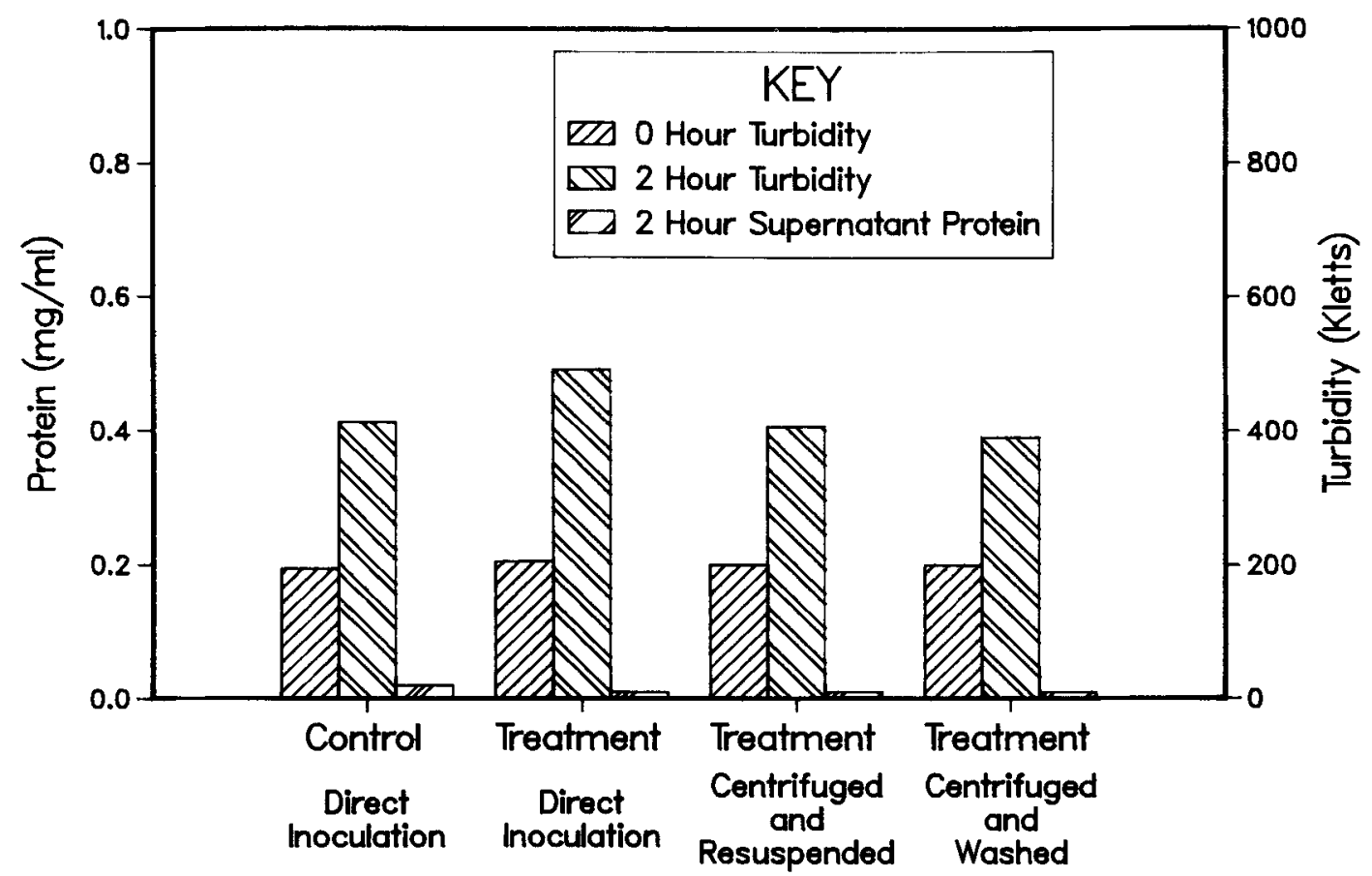

Figure 6. Turbidity and supernatant protein concentration of $E$. coli C600-1 cultures treated with $0.2 \mathrm{M}$ guanidine plus $0.5 \%$ Triton $\mathrm{X}-100$. At time zero, one volume of sterile treatment chemicals in buffer was added to three volumes of culture. The control consists of sterile buffer added to culture. Immediately prior to dilution with treatment chemicals, the precultures were grown in control medium using inocula from a culture treated overnight in medium containing $0.2 \mathrm{M}$ guanidine plus $0.5 \%$ Triton X-100. Precultures were inoculated either by 20:1 dilution in fresh medium (designated "Direct Inoculation"), or by 20:1 dilution in fresh medium of cells that had been "centrifuged and resuspended" in their own supernatant four times, or by 20:1 dilution in fresh medium of cells that had been "centrifuged and washed" in sterile medium four times.

treatment chemicals present in the liquid medium during growth of the culture prior to a permeabilization experiment render the cells partially resistant to the treatment. For cultures grown with either a 100:1 or 10:1 dilution of $0.2 \mathrm{M}$ guanidine plus $0.5 \%$ Triton X-100 present, growth continues and protein release is very low upon addition of treatment chemicals to a final concentration of $0.2 \mathrm{M}$ guanidine plus $0.5 \%$ Triton X-100. Furthermore, there is no additional lag phase upon inoculating control cells to liquid medium containing a $100: 1$ or a $10: 1$ dilution of $0.2 M$ guanidine plus $0.5 \%$ Triton X-100 (data not shown). Thus, the chemicals ap- pear to be inducing a physiological adaptation, not selecting for a genetic mutation.

Given the bimodal distribution in Figure 4, as well as the considerable evidence that $E$. coli cultures actually contain heterogeneous subpopulations with varying responses to treatment by guanidine and Triton X-100, ${ }^{4}$ it is possible that not all of the cells are able to adapt to the presence of the treatment chemicals. It is also possible that the resistant cells are the result of a discrete mutation that is disadvantageous under nonselective conditions. However, the results presented here strongly indicate that the resistance to treatment exhibited by

Table IV. Loss of $E$. coli $\mathrm{C} 600-1$ resistance to treatment after many generations of growth in the absence of treatment chemicals.

\begin{tabular}{lcc}
\hline & $\begin{array}{c}\text { Specific growth } \\
\text { rate of culture }\end{array}$ & $\begin{array}{c}\text { Protein release after } 2 \mathrm{~h} \\
\text { exposure to } 0.2 \mathrm{M} / 0.5 \%\end{array}$ \\
\hline $\begin{array}{l}\text { Control } \\
\text { Colonies isolated } \\
\text { from } 0.2 \mathrm{M} \text { guHCl/ }\end{array}$ & $1.04 \pm 0.097 \mathrm{~h}^{-1}$ & $23 \% \pm 1.7 \%$ \\
$0.5 \%$ Triton X-100 culture & $0.93 \pm 0.019 \mathrm{~h}^{-1}$ & $22 \% \pm 4.8 \%$ \\
\hline
\end{tabular}

Three colonies were isolated from a culture grown overnight in the presence of $0.2 \mathrm{M}$ guanidine plus $0.5 \%$ Triton $\mathrm{X}-100$ by plating on control agar and then picking single colonies to grow in suspension overnight in $10 \mathrm{~mL}$ control medium. These precultures were then inoculated to fresh control medium at 100:1 dilution. The growth rate and subsequent response to the treatment is the same as for control cells (which have never been exposed to guanidine or Triton X-100) inoculated to fresh control medium at 100:1 dilution. Standard deviations based on at least three determinations. 


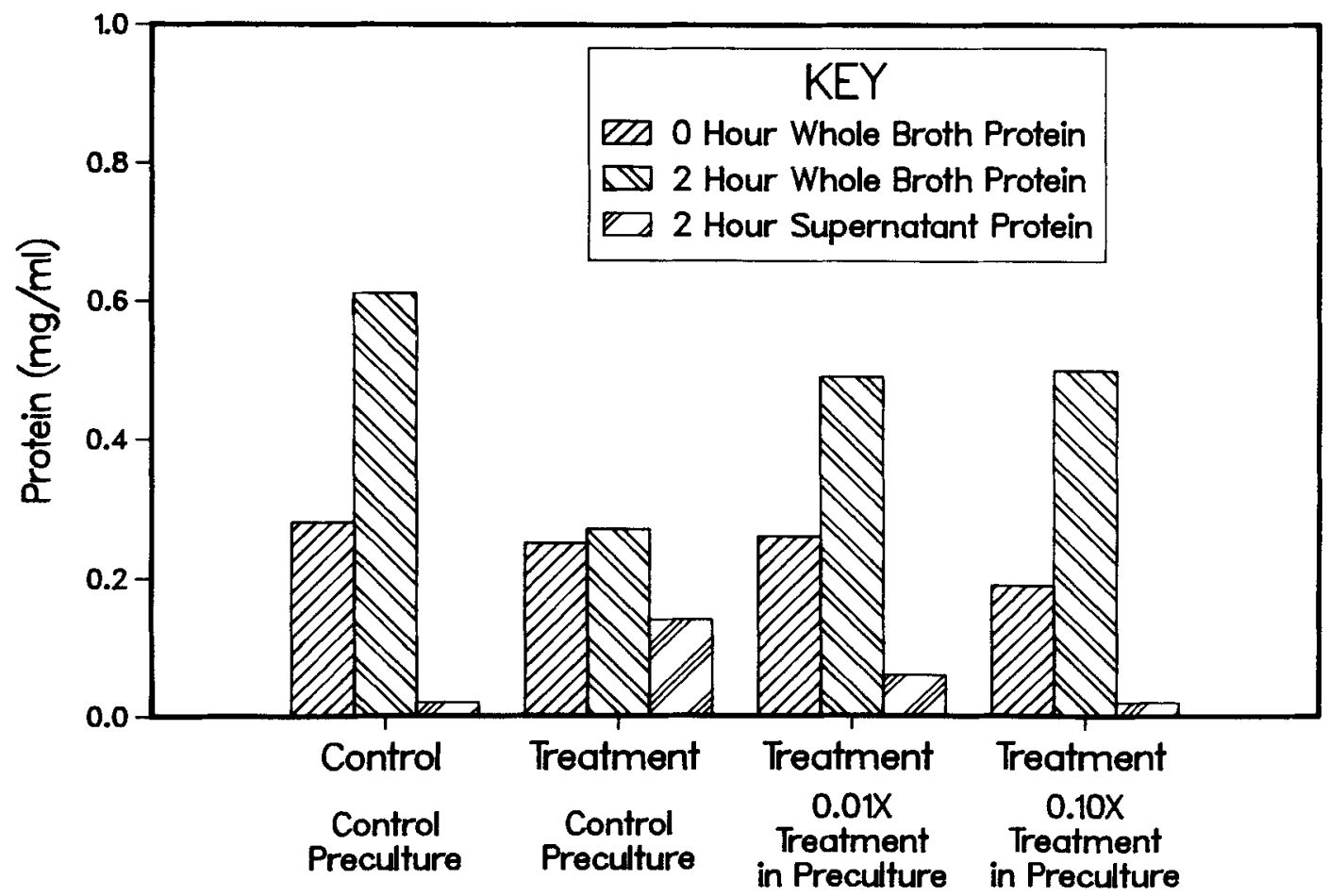

Figure 7. Whole broth protein concentration and supernatant protein concentration of $E$. coli C600-1 cultures grown in the presence of guanidine and Triton X-100 and then treated with $0.2 \mathrm{M}$ guanidine plus $0.5 \%$ Triton $\mathrm{X}-100$. At time zero, one volume of sterile treatment chemicals in buffer was added to three volumes of culture. The control consists of sterile buffer added to culture. Immediately prior to dilution with treatment chemicals, the precultures were grown either in control medium or in medium containing $000.2 \mathrm{M}$ guanidine plus $0.005 \%$ Triton X-100 (designated " $0.01 \mathrm{X}$ Treatment") or in medium containing $0.02 \mathrm{M}$ guanidine plus $0.05 \%$ Triton X-100 (designated "0.10X Treatment").

cells grown in the presence of guanidine and Triton $\mathrm{X}-100$ is the result of a phenotypic adaptation rather than a genetic mutation. A trace amount of the chemicals can, in just a few generations, elicit nearly full resistance to the treatment without incurring any additional lag phase during growth. Hence, a significant portion of the cells is probably capable of developing resistance to permeabilization by guanidine and Triton X-100 because of reversible, physiological adaptation.

\section{CONCLUSIONS}

Exposure of exponentially growing $E$. coli cells to guanidine and Triton $\mathrm{X}-100$ at $37^{\circ} \mathrm{C}$ in medium results in rapid release of intracellular protein at the expense of continued cell growth. Protein release greater than $75 \%$ can be attained in less than $1 \mathrm{~h}$ by exposing the cells to $0.4 M$ guanidine plus $0.5 \%$ Triton X-100. Cell growth resumes, after a suitable lag phase, upon removal of these chemicals. Guanidine concentrations lower than $0.2 M$, in conjunction with $0.5 \%$ Triton X-100, neither release significant intracellular protein nor inhibit cell growth. Under these conditions, the cells undergo a reversible physiological adaptation that confers resistance to protein release by treatment with guanidine and Triton $\mathrm{X}-100$. Cells treated with $0.2 \mathrm{M}$ guanidine plus $0.5 \%$ Triton X-100 display intermediate behavior. Cell growth halts immediately, and protein release is approximately $35 \%$ within $3 \mathrm{~h}$. Growth resumes, however, after an extended lag phase, even without removal of the chemicals. No further protein is released, and the cells display resistance to further treatment. Culture of resistant cells for many generations in the absence of the treatment chemicals reverses the adaptation, resulting in cells that are again susceptible to rapid protein release by treatment with guanidine and Triton X-100.

The authors wish to thank Professor Fred Neidhardt of the Department of Microbiology and Immunology at the University of Michigan for his many helpful discussions. The financial support of the National Science Foundation, Grant No. ECE-8603976, is also gratefully acknowledged.

\section{References}

1. Blanchin-Roland, S., Masson, J. 1989. Protein secretion controlled by a synthetic gene in Escherichia coli. Protein Eng. 2: $473-480$.

2. Bradford, M. 1976. A rapid and sensitive method for the quantitation of microgram quantities of protein utilizing the principle of protein-dye binding. Anal. Biochem. 72: 248.

3. Georgiou, G., Shuler, M. L., Wilson, D. B. 1988. Release of periplasmic enzymes and other physiological effects of $\beta$-lactamase overproduction in Escherichia coli. Biotechnol. Bioeng. 32: 741-748.

4. Hettwer, D. J. 1987. Protein release from Escherichia coli cells permeabilized with guanidine- $\mathrm{HCl}$ and Triton X100, Ph.D. Thesis, The University of Michigan, Ann Arbor, MI, USA.

5. Hettwer, D., Wang, H. 1989. Protein release from Escherichia coli cells permeabilized with guanidine- $\mathrm{HCl}$ and Triton $\mathrm{X} 100$. Biotechnol. Bioeng. 33: 886-895. 
6. Lundell, D., Greenberg, R., Alroy, Y., Condon, R., Fossetta, J. D., Gewain, K., Kastelein, R., Lunn, C. A., Reim, R., Shah, C., van Kimmenade, A., Narula, S. K. 1990. Cytoplasmic and periplasmic expression of a highly basic protein, human interleukin 4, in Escherichia coli. J. Industrial Microbiol. 5: 215-228.

7. Manin, C., Barbotin, J. N., Thomas, D., Lazzaroni, J. C., Portalier, R. 1989. Production of alkaline phosphatase by immobilized growing cells of Escherichia coli excretory mutants. Appl. Microbiol. Biotechnol. 32: 143-147.

8. Miyazaki, H., Yanagida, N., Horinouchi, S., Beppu, T. 1989. Characterization of the precursor of Serratia marcescens serine protease and $\mathrm{COOH}$-terminal processing of the precursor during its excretion through the outer membrane of Escherichia coli. J. Bacteriol. 171: 6566-6572.

9. Naglak, T. J., Wang, H.Y. 1990. Recovery of a foreign protein from the periplasm of Escherichia coli by chemical permeabilization. Enzyme Microbiol. Technol. 12: 603-611.

10. Sargent, M.G. 1968. Rapid fixed-time assay for penicillinase. J. Bacteriol. 95: 1493-1495.

11. van Kimmenade, A., Dang, W., Kastelein, R. A. 1989. Secretion of murine and human interleukin- 2 by Esherichia coli. J. Biotechnol. 11: 11-24. 